\title{
Količina humusa u tlima za podizanje trajnih nasada u Hrvatskoj
}

\author{
Humus content in soils intended for establishment of permanent \\ plantations in Croatia
}

\author{
A. Biško, Bernardica Milinović, Z. Savić, Vesna Jurkić, \\ Sanja Slunjski, L. Čoga
}

\section{SAŽETAK}

Humus ima specifičnu, višestruko pozitivnu ulogu u fizikalnim, kemijskim i mikrobiološkim značajkama tla. Doprinosi formiranju stabilnih agregata, strukturi tla, aeraciji, poboljšanju ritma infiltracije i povećanju kapaciteta skladištenja vode. Kao skladište za biljna hraniva ujedno je izvor plodnosti tla. Također, služi kao pufer protiv brzih promjena reakcije tla $(\mathrm{pH})$ i djeluje kao izvor energije za mikroorganizme $\mathrm{u}$ tlu. Uvažavajući gore iznijeto, kao i činjenicu da trajni nasadi (voćnjaci i vinogradi) na istoj površini ostaju dugi niz godina te da je potrebno žurno formirati tratinu u međurednom prostoru, poznavanje razine humusa u tlima namijenjenim za podizanje voćnjaka i vinograda je od izuzetne važnosti.

Temeljem analiza cca četiri tisuće uzoraka tla (računajući oranični sloj 0-30 cm i podoranični sloj 30-60 cm) iz 16 županija Republike Hrvatske, utvrđena je količina humusa. Uzorci tla uzeti su u periodu od 2000. do 2006. godine, tj. u vrijeme kad se krenulo u znatnije podizanje voćnjaka i vinograda, popraćeno poticajima za podizanje trajnih nasada (Biško i sur., 2005a.; Biško i sur. 2005b.).

Količina humusa određena je metodom po Tjurinu (Škorić i Seretić 1966.). U konačnici, izračunate su i prosječne vrijednosti (\% humusa) oraničnog i podoraničnog sloja tla što čini ukupno 2.038 uzoraka i predstavlja isto toliko proizvodnih površina sa kojih su uzeti prosječni uzorci. Prosječne vrijednosti količine humusa po pojedinoj županiji kretale su se od 1,53 \% u Virovitičko-podravskoj do 3,32 \% u Primorskogoranskoj županiji. U ostalim županijama utvrđene su sljedeće prosječne vrijednosti humusa: Koprivničko-križevačka 1,54 \%, Požeško-slavonska 1,62 \%, Vukovarskosrijemska 1,63 \%, Bjelovarsko-bilogorska 1,78 \%, Brodsko-posavska 1,80 \%, Zadarska

i Međimurska 2,01 \%, Sisačko-moslavačka 2,13\%, Istarska 2,15\%, Zagrebačka $2,22 \%$, Krapinsko-zagorska 2,23 \%, Karlovačka 2,44 \%, Šibensko-kninska 2,74 \% i Ličko-senjska 2,89\%.

Utvrđene vrijednosti uspoređene su s Izvješćem Europskog ureda za istraživanje tala (Br. 15) Europske Komisije: „Organic Matter in the Soils of Southern Europe”, Zdruli i sur., 2004.

Ključne riječi: humus, organska tvar, voćnjak, vinograd 


\begin{abstract}
Humus has a specific, multiple positive influence on physical, chemical and microbiological soil characteristics. It contributes to the formation of stable aggregates, soil structure and aeration, improvement of infiltration rhythm and to an increase of water storage capacity. Being a storage for plant nutrients, it is a source of fertility at the same time. Furthermore, it is also a buffer against rapid changes in soil reaction $(\mathrm{pH})$ and acts as an energy source for microorganisms in the soil. Taking into consideration aforementioned, as well as the fact that permanent plantations (orchards and vineyards) stay in the same area for a longer time, the need for urgent growth of grass between rows, understanding levels of humus in soils intended for establishment of orchards and vineyards is of utmost importance.

Based on the analysis of approximately four thousand soil samples (including topsoil $0-30 \mathrm{~cm}$ and subsoil $30-60 \mathrm{~cm}$ ) from 16 counties in the Republic of Croatia, humus content was determined. Soil samples were taken in the period between 2000 and 2006 , in the time of planting major orchards and vineyards, accompanied by incentives for setting us permanent plantations (Biško et al., 2005a; Biško et al. 2005b).

Humus content was determined by Tjurin method (Škorić i Sertić, 1966). Finally, mean values (\% humus) of topsoil and subsoil were calculated which accounts for 2.038 samples, representing the same number of plots from which samples were taken.

Mean values of humus content per each county ranged between $1.53 \%$ in Virovitičko-podravska County and $3.32 \%$ in Primorsko-goranska County. For other counties the following mean values of humus content were determined: Koprivničkokriževačka $1.54 \%$, Požeško-slavonska 1.62\%, Vukovarsko-srijemska $1.63 \%$, Bjelovarsko-bilogorska 1.78\%, Brodsko-posavska 1.80\%, Zadarska and Međimurska 2.01\%, Sisačko-moslavačka $2.13 \%$, Istarska $2.15 \%$, Zagrebačka $2.22 \%$, Krapinsko-zagorska $2.23 \%$, Karlovačka $2.44 \%$, Šibensko-kninska $2.74 \%$ and Ličko-senjska $2.89 \%$.

Identified values were compared with the Report of the European Office for Soil Research (No 15) of the European Commission: "Organic Matter in the Soils of Southern Europe, Zdruli, et al. 2004.
\end{abstract}

Key words: humus, organic matter, orchard, vineyard

\title{
UVOD
}

Stoljećima je organska tvar tla smatrana eliksirom života biljaka. Vrlo rano u povijesti, čovjek je otkrio da je boja tla izravno povezana s organskom tvari koja uglavnom nastaje raspadom biljnog materijala. Ustanovljeno je da su tla $\mathrm{s}$ visokim sadržajem organske tvari produktivnija i za proizvodnju usjeva i za pašnjake za ispašu stoke. Da bi se stoga osiguralo održivo gospodarenje tlom, neophodno je gospodariti i održavati organsku tvar na prihvatljivoj razini. Smanjenje količine organske tvari je indikator smanjenja kvalitete $u$ većine tala. 
Razlog tomu je što je organska tvar tla vrlo važna u svim procesima koji se događaju u tlu (Zdruli i sur., 2004).

U posljednjih 50 godina tlo je pod snažnim utjecajem ljudske aktivnosti: širenje i unos različitih zagađivača u obliku čestica, kiselih kiša, primjene pesticida i herbicida, utjecaju erozije, primjene različitih otpadnih muljeva, eksploatacije mineralnih sirovina, trajnog zbijanja i uništavanja strukture, zagađenja tala i površinskih voda agrokemijskim i atmosferskim zagađivačima, što sve zajedno utječe na kemijske, fizikalne i mikrobiološke osobine tla, a time i samu plodnost tla (Zdruli i sur., 2004). Povećanje i održavanje razine organske tvari u tlima smanjuje navedene negativne utjecaje. Koncentracija mineralnih hraniva u otopini tla varira, ovisno o čimbenicima kao što su vlažnost tla, dubina tla, $\mathrm{pH}$, kapacitet izmjene kationa, redoks potencijal, količina organske tvari u tlu, mikrobiološka aktivnost, godišnje doba i primjena gnojiva (Marschner, 1995).

U mineralnim tlima, koncentracija i pokretljivost fosfata je povećana kompleksiranjem sesquioksida $\mathrm{s}$ organskim ligandima; organska tvar tla i mikrobiološka aktivnost stoga povećavaju koncentraciju i pokretljivost fosfata (Seeling i Zasoski, 1993), što vodi do visokog postotka organski vezanih formi (P org) u otopini tla.

Količina organske tvari u tlima namijenjenim za podizanje trajnih nasada izuzetno je bitna te je istu potrebno podići na odgovarajuću razinu prije zasnivanja trajnih nasada jer naknadno nije moguće kvalitetno reagirati niti izvršiti unos i raspodjelu iste u zonu rizosfere. Osim kultiviranih višegodišnjih vrsta (voćnjaka i vinograda), razina organske tvari ima pozitivnu ulogu i na rast travnih smjesa kojima se formira tratina u međurednom pojasu, a time naknadno i utjecaj na povećanu razinu nakupljanja organske tvari u tlu tijekom amortizacijskog razdoblja voćnjaka.

Cilj istraživanja je izvršiti prikupljanje, obradu i analizu raspoloživih podataka o količini humusa u tlima namijenjenim za podizanje trajnih nasada, temeljem prosječnih vrijednosti utvrditi prostornu raspodjelu - klasificiranje tala po pojedinim županijama sukladno klasifikaciji po Gračaninu (Škorić, 1961), usporediti dobivene rezultate s procijenjenim vrijednostima koje su prikazane u Izvješću Europskog ureda za istraživanje tala, „Organic Matter in the Soils of Southern Europe“" (Zdruli i sur., 2004), te dati osnovne preporuke u pogledu očuvanja i povećanja organske tvari u tlima, kao i u strateškom planiranju, analizama, i izvještavanju o sadržaju i dinamici organske tvari u poljoprivrednim tlima Republike Hrvatske. 


\section{MATERIJAL I METODE}

Prikupljani su podaci iz Tehnoloških elaborata za podizanje trajnih nasada, temeljem podnijetih zahtjeva za potporu Ministarstvu poljoprivrede Republike Hrvatske, te iz baza podataka Analitičkog laboratorija Zavoda za ishranu bilja Agronomskog fakulteta Sveučilišta u Zagrebu. Obrada i analiza prikupljenih podataka, te grafička obrada istih obavljena je u programu Excel 2010.

\section{REZULTATI I RASPRAVA}

Provedena istraživanja pokazuju da velika većina tala Republike Hrvatske namijenjenih za podizanje trajnih nasada ima nisku razinu humusa (Grafikoni 1 i 2). Utvrđena je značajna razlika u prosječnim količinama humusa ovisno o području istraživanja (pojedina županija), kao i unutar samih županija ovisno o položajima i namjeni površina. Primjerice, Vukovarsko-srijemska županija (ukupno analizirani uzorci sa 381 proizvodne površine, od čega 228 za vinograde i 153 za voćnjake) imala je $17 \%$ višu razinu humusa u tlima namijenjenim za podizanje voćnjaka nego tla namijenjena za podizanje vinograda, dok su prosječne vrijednosti humusa u podoraničnom sloju, kod svih tala, bile za $20 \%$ niže (vinogradi: oranični sloj $1,66 \%$, podoranični $1,33 \%$, voćnjaci: oranični sloj $2,01 \%$, podoranični $1,60 \%$ ). U odnosu na prosječnu vrijednost postotka humusa $(2,13 \%)$ oraničnog i podoraničnog sloja $(0-60 \mathrm{~cm})$ dobivenu od uzoraka analiziranih županija, prosječne županijske vrijednosti bile su značajno više u Ličko-senjskoj (36\%) i Primorsko-goranskoj (56\%), a značajno niže u Koprivničko-križevačkoj i Virovitičko-podravskoj (cca po $28 \%$ u svakoj od njih). Navedeno relativno povećanje, odnosno smanjenje u odnosu na nacionalne prosječne vrijednosti ukazuje na značajne razlike u stupnju opskrbljenosti ispitivanih tala humusom. Utvrđena razlika je uvelike uvjetovana različitim matičnim supstratom, mehaničkim sastavom, $\mathrm{pH}$ vrijednosti, kao i načinom gospodarenja predmetnim tlima.

Ukoliko usporedimo prosječne vrijednosti količine humusa $\mathrm{u}$ oraničnom sloju $(0-30 \mathrm{~cm})$, po pojedinim županijama (Grafikon 2), razvidno je da samo dvije županije (Primorsko-goranska i Ličko-senjska) imaju tla dosta opskrbljena humusom tj. utvrđena količina humusa kreće se u rasponu 3-5\% (Škorić, 1961, cit. klasifikacije po Gračaninu). Povećane vrijednosti postotka humusa u oraničnom sloju tala Ličko-senjske (56\%) i Primorsko-goranske (71\%), odnosno smanjene vrijednosti u tlima Virovitičko-podravske i Vukovarskosrijemske županije $(13 \%$ i $14,6 \%)$, u odnosu na prosječne vrijednosti svih 
Grafikon 1: Prosječne količine humusa $(0-60 \mathrm{~cm})$; prikaz po županijama

Graph 1 Mean humus content $(0-60 \mathrm{~cm})$; county overview

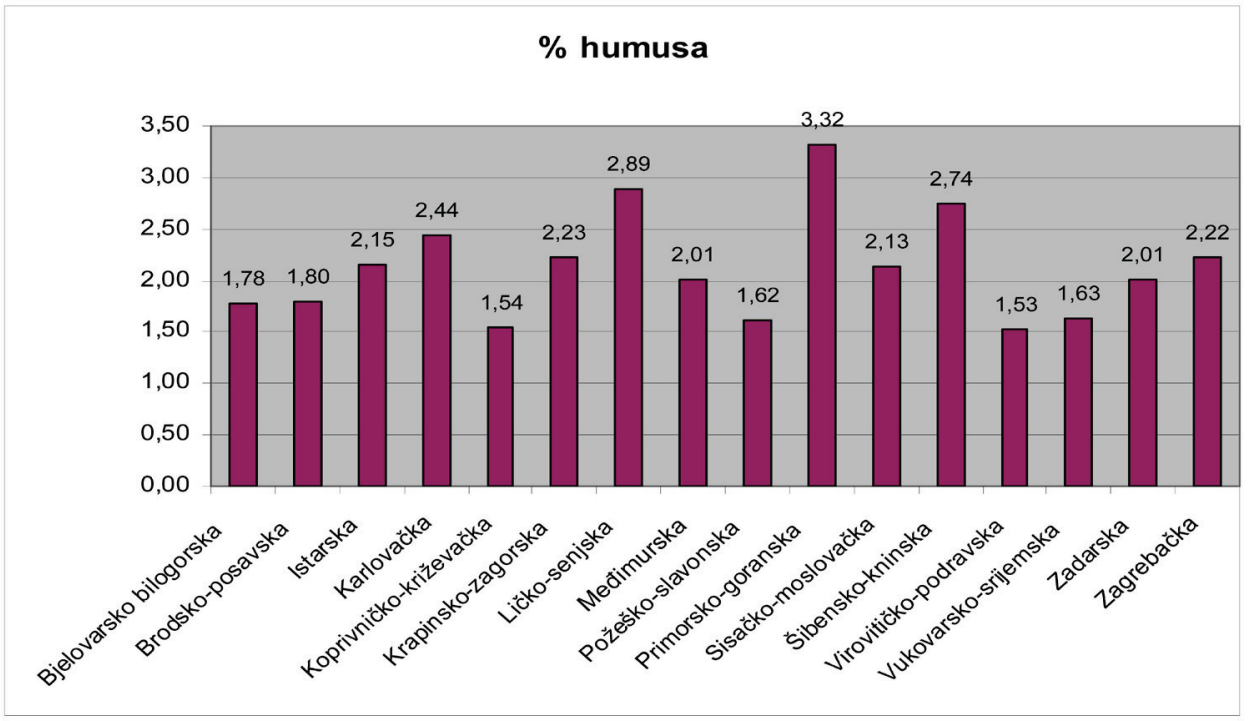

Grafikon 2: Prosječne količine humusa $(\%)$ u oraničnom sloju tla $(0-30 \mathrm{~cm})$, Graph 2 Mean humus content (\%) in topsoil $(0-30 \mathrm{~cm})$

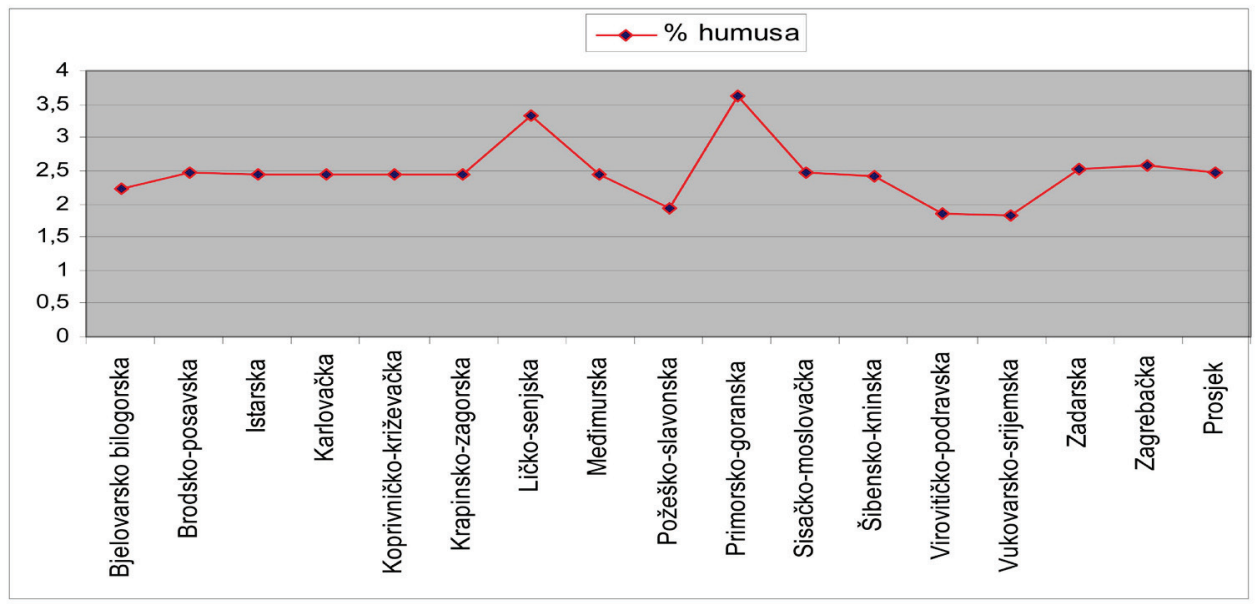

analiziranih uzoraka (2,47\%) ukazuje na značajne razlike u stupnju opskrbljenosti ispitivanih tala humusom. 
Također, ako usporedimo prosječne vrijednosti sadržaja humusa oraničnog sloja (Grafikon 2) s prosječnim vrijednostima oraničnog i podoraničnog sloja zajedno (Grafikon 1), razvidno je da imamo daleko ujednačeniju situaciju tj. manje kolebanje prosječnih vrijednosti (promatrano među županijama) u oraničnom sloju; tako deset županija ima prosječne vrijednosti približno na prosječnoj razini Republike Hrvatske (cca 2,5\% humusa), dočim Bjelovarskobilogorska, Požeško-slavonska, Virovitičko-podravska i Vukovarsko-srijemska imaju značajno niže, a Ličko-senjska i Primorsko-goranska značajno više vrijednosti u odnosu na prosjek Republike Hrvatske. Ako usporedimo dobivene prosječne vrijednosti humusa u oraničnom sloju s procijenjenim vrijednostima Izvješća Europskog ureda za istraživanje tala, razvidno je da samo jedna županija (Primorsko-goranska) u svojim tlima ima više od 3,4\% humusa, što odgovara ekvivalentu od $2 \%$ organskog ugljika. (Zdruli i sur., 2004). Budući da je Ličko-senjska županija tek nešto ispod tog praga (3.33\% humusa) i nju bismo uvjetno mogli svrstati u kategoriju tala s $2 \%$ organskog ugljika. Relativna zastupljenost uzoraka $\mathrm{s}$ količinom humusa $>3,4 \%$ humusa $(2 \%$ organskog ugljika) u oraničnom sloju tla pokazuje da se on kreće od 50\% u Primorskogoranskoj županiji do samo $0,52 \%$ u Vukovarsko-srijemskoj županiji; prosjek $15,1 \%$ za sve analizirane uzorke na području Republike Hrvatske. Posebice zabrinjava činjenica da su na samom začelju četiriju županija Istočne Hrvatske u kojima je manje od 3\% površina s količinom humusa $>3,4 \%$ (Grafikon 6).

\section{Grafikon 3: Raspodjela i broj analiziranih uzoraka sukladno klasifikaciji po Gračaninu* u oraničnom i podoraničnom sloju $(0-60 \mathrm{~cm})$}

\section{Graph 3 Distribution and number of analyzed samples according to Gračanin* classification in topsoil and subsoil}

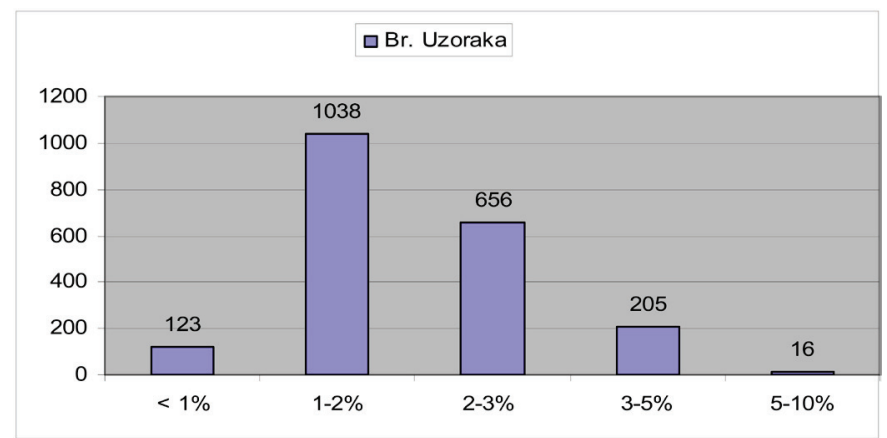

\footnotetext{
*klasa opskrbljenosti 1-3\% humusa (slabo humozna tla) dodatno je rasčlanjena na dvije potklase:1-2\% i 2-3\% humusa

*class of 1-3 \% humus supply (soils with low humus content) additionally decomposed to two subclasses: 1$2 \%$ and $2-3 \%$ humus
} 
A. Biško i sur.: Količina humusa u tlima za podizanje trajnih nasada u Hrvatskoj

\section{Grafikon 4: Postotni udio analiziranih uzoraka sukladno klasifikaciji po Gračaninu u oraničnom i podoraničnom sloju $(0-60 \mathrm{~cm})$}

Graph 4 Share (\%) of analyzed samples according to Gračanin classification in topsoil and subsoil $(0-60 \mathrm{~cm})$

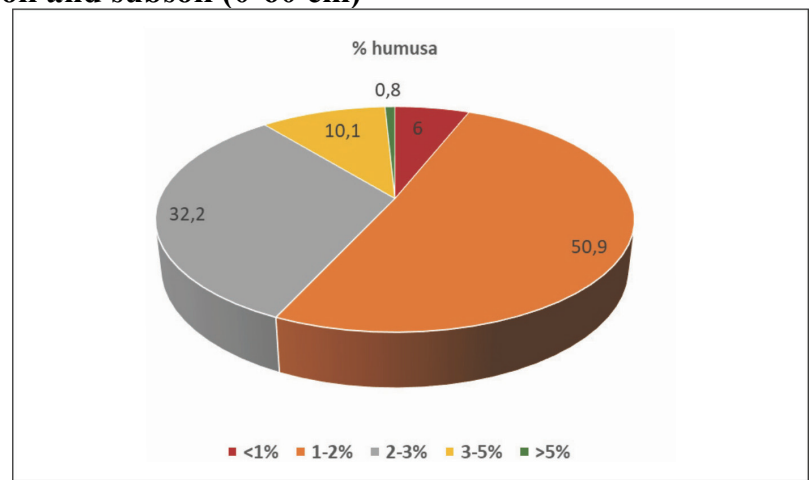

*klasa opskrbljenosti 1-3\% humusa (slabo humozna tla) dodatno je rasčlanjena na dvije podklase: $1-2 \%$ i $2-3 \%$ humusa

*class of 1-3\% humus supply (soils with low humus content) additionally decomposed to two subclasses: 1 $2 \%$ and $2-3 \%$ humus

\section{Grafikon 5: Postotni udio analiziranih uzoraka sukladno klasifikaciji po Gračaninu u oraničnom sloju tla $(0-30 \mathrm{~cm})$}

Graph 5 Share (\%) of analyzed samples according to Gračanin classification in topsoil $(0-30 \mathrm{~cm})$

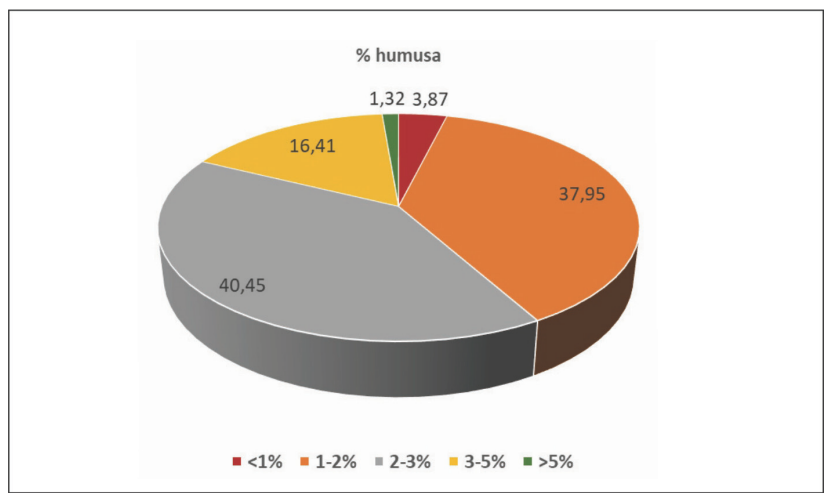

*klasa opskrbljenosti 1-3\% humusa (slabo humozna tla) dodatno je rasčlanjena na dvije podklase: $1-2 \%$ i 2-3\% humusa

*class of 1-3\% humus supply (soils with low humus content) additionally decomposed to two subclasses: 1$2 \%$ and $2-3 \%$ humus 
Raspodjela i broj analiziranih uzoraka (Grafikon 3) kao i postotni udio analiziranih uzoraka sukladno klasifikaciji po Gračaninu (Grafikoni 4 i 5), zorno prikazuju nizak kvantitativni udio humusa u analiziranim tlima. . Klasa slabo humoznih tala (1-3\% humusa) dodatno je raščlanjena na udio od 1-2\% i 2-3\% humusa (Grafikon 3). Izuzetno visok postotak vrlo slabo humoznih i slabo humoznih tala, (ukupno 89,1\%) ukazuje na loše stanje kad je u pitanju količina humusa u tlima namijenjenima za podizanje trajnih nasada. Promatrano $\mathrm{u}$ postocima, $6 \%$ analiziranih proizvodnih površina ima manje od $1 \%$ humusa, što ih svrstava u vrlo slabo humozna tla, $83 \%$ slabo humozna (od čega $51 \%$ parcela $1-2 \%$, a $32 \%$ parcela $2-3 \%$ humusa), $10 \%$ parcela ima $3-5 \%$ humusa - dosta humozna, a samo $0,8 \%$ parcela ima $5-10 \%$ humusa, što ih svrstava u kategoriju jako humoznih tala (u stvari se radilo o vrijednostima koje su bile tek nešto iznad 5\% humusa). Ako promatramo postotak humusa u oraničnom sloju tla (0-30 cm), očekivano tada imamo nešto bolju situaciju: 3,9\% tala ima manje od $1 \%$ humusa (vrlo slabo humozna tla), 78,4 \% slabo humoznih (od čega 38,0\% parcela 1-2\% humusa, a 40,5\% 2-3\% humusa), 16,4\% dosta humoznih tala (3-5\% humusa) i samo 1,32\% jako humoznih tala (5-10\% humusa), Grafikon 5 .

Ovakvi rezultati su jednim dijelom očekivani jer se predmetne površine nalaze u Južnoj Europi gdje je, prvenstveno zbog klimatskih prilika, usporena izgradnja, a istodobno ubrzana razgradnja i mineralizacija organske tvari. Također, u posljednjih tridesetak godina zbog poremećaja u kontinuitetu zatvorenog ciklusa stočarske i biljne proizvodnje očekivano je smanjenje razine organske tvari, a time i humusa.

\section{Grafikon 6: Relativna zastupljenost uzoraka s količinom humusa $>\mathbf{3 , 4} \%$}

Graph 6 Relative share of samples with humus content $>3,4 \%$

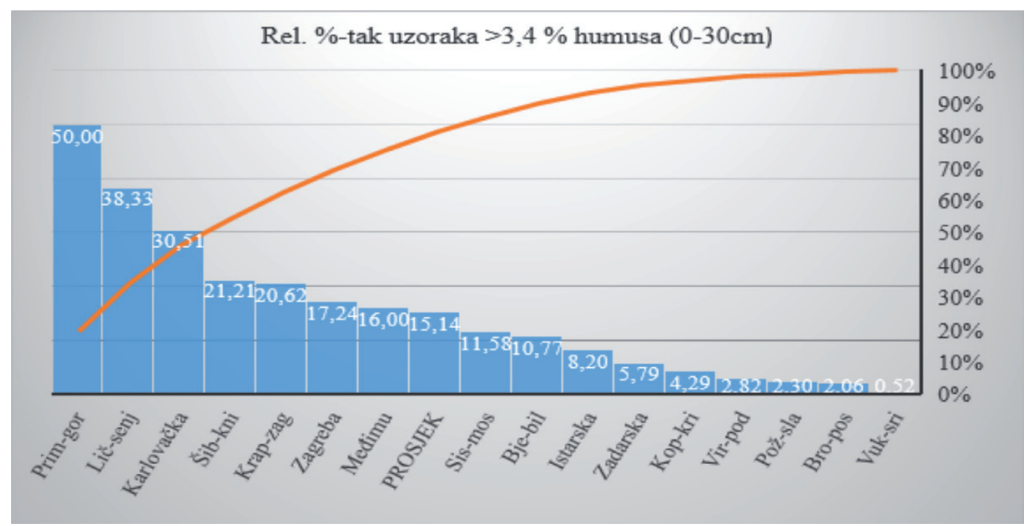


Isticanje problematike kvalitete tla općenito, a posebice količine organske tvari, visoko je na ljestvici prioriteta EK prilikom planiranja održivog korištenja zemljišnih resursa.

Uvažavajući predmetne rezultate, važnost organske tvari u tlu, Izvješće Europskog ureda za istraživanje tala (Zdruli i sur., 2004), ratifikaciju Konvencije o suzbijanju dezertifikacije (NN, 11/2000), Nitratnu direktivu (NN, 15/2013 i Direktivu Vijeća EEZ, 91/676/EEZ), dosadašnje neodgovorno gospodarenje stajskim gnojem i organskim ostacima, te tlom općenito, potrebne su žurne i korjenite promjene na bolje. Snažnije uključivanje dobre poljoprivredne prakse s ciljem smanjenja erozije, kvalitetnog upravljanja zemljištem uvažavajući specifične značajke pojedinog tipa tla, kvalitetno upravljanje organskim ostacima, te primjereno korištenje mehanizacije, doprinijet će zaustavljanju daljnjeg pada organske tvari u tlu. Zaustavljanje pada, povećanje i održavanje razine organske tvari u poljoprivrednim tlima prioritet je i izazov poljoprivrednim proizvođačima, čija je obaveza stalno usvajanje i primjena strogih propisa koji poseban naglasak stavljaju na pojačanu zaštitu okoliša i podzemnih voda, što uključuje zbrinjavanje, čuvanje, primjenu gnojiva (rokovi, vrste, količine, načine primjene), kao i ostalih materijala koji se koriste u poljoprivrednoj proizvodnji (NN, 15/2013 i Direktiva Vijeća EEZ, 91/676/EEZ).

\section{ZAKLJUČCI}

Temeljem rezultata istraživanja zaključujemo sljedeće:

- postotni udio humusa u tlima za podizanje voćnjaka i vinograda u Republici Hrvatskoj je nizak; što posebice zabrinjava jer je riječ o intenzivnim nasadima,

- sukladno klasifikaciji po Gračaninu, postotni udio humusa u oraničnom horizontu $(0-30 \mathrm{~cm})$ bio je: $3,9 \%$ vrlo slabo humozna tla $(<1 \%), 78,5 \%$ slabo humozna tla $(1-3 \%), 16,4 \%$ dosta humozna tla (3-5\%) i 1,3\% jako humozna tla (5-10\% humusa), dok je on u oraničnom i podoraničnog sloju (prosjek: 0-30 i 30-60 cm) bio: $6 \%$ vrlo slabo humozna tla $(<1 \%), 83,1 \%$ slabo humozna tla $(1-3 \%)$, $10,1 \%$ dosta humozna tla $(3-5 \%)$ i $0,8 \%$ jako humozna tla $(5-10 \%$ humusa),

- relativna zastupljenost uzoraka s količinom humusa $>3,4 \%(2 \%$ organskog ugljika) u oraničnom sloju tla pokazuje da se on kreće od $50 \%$ u Primorsko-goranskoj županiji do samo 0,52\% u Vukovarsko-srijemskoj županiji. Posebice zabrinjava činjenica da 
su na samom začelju četiri županije Istočne Hrvatske u kojima je manje od $3 \%$ površina $\mathrm{s}$ količinom humusa $>3,4 \%$ u oraničnom sloju tla.

\section{LITERATURA}

BIŠKO, A., VUJEVIĆ, P., PERA, S., JELAČIĆ, T., SAVIĆ, Z. i HALAPIJA, D. : (2005.a) Učinak poticaja za podizanje voćnjaka u Republici Hrvatskoj za razdoblje 2000.-2002.godine, str. 689-690., 40. ZNANSTVENI SKUP HRVATSKIH AGRONOMA" Opatija 15.-18. veljače 2005"

BIŠKO, A., JELAČIĆ, T., KUREK, S., LUCEVIĆ, A., i MILAT, V. (2005.b): Učinak poticaja za podizanje vinograda u Republici Hrvatskoj za razdoblje 2000.-2002. godine, str. 691-692., 40. ZNANSTVENI SKUP HRVATSKIH AGRONOMA", str. 689-690., Opatija 15.-18. veljače 2005."

COUNCIL DIRECTIVE (91/676/EEC) of 12 December 1991 concerning the protection of waters against pollution caused by nitrates from agricultural sources /Direktiva Vijeća od 12. prosinca 1991. o zaštiti voda od onečišćenja uzrokovanog nitratima iz poljoprivrednih izvora/ (91/676/EEZ).

MARSCHNER, H. (1995.): Mineral Nutrition of Higher Plants, $2^{\text {nd }}$ Edition, Academic Pres, London, San Diego, New York, Boston, Sydney, Tokio, Toronto, str. 486.

NARODNE NOVINE (15/2013.): Ministarstvo poljoprivrede, Akcijski program zaštite voda od onečišćenja uzrokovanog nitratima poljoprivrednog podrijetla.

SEELING, B i ZASOSKI, R. J. (1993.): Microbial effects in maintaining organic and inorganic solution phosphorus concentrations in a grassland topsoil. Plant Soil 148, 277-284.

ŠKORIĆ, A. (1961.): Pedološka istraživanja (Priručnik) Zagreb

ŠKORIĆ, A., i SERTIĆ, V. (1966.): Analiza organske materije (humusa) zemljišta, Određivanje ukupne količine ugljika i humusa: Određivanje ugljika i humusa po Tjurinu, Priručnik za ispitivanje zemljišta, Knjiga I Kemijske metode ispitivanja zemljišta, JDPZ-Jugoslavensko društvo za proučavanje zemljišta (1966), str. 42-43. 
NARODNE NOVINE (11/2000) Zakon o potvrđivanju konvencije Ujedinjenih naroda o suzbijanju dezertifikacije u zemljama pogođenim jakom sušom i/ili dezertifikacijom, osobito u Africi; Broj:01-081-00-3177/2, od 30. rujna 2000 .

ZDRULI, P., JONES, R.J.A., and MONTANARELLA, L. (2004.): Organic Matter in the Soils of Southern Europe. European Soil Bureau Technical Report, EUR 21083 EN,16pp. Office for Official Publications of the European Communities, Luxembourg).

\section{Adrese autora - Author's address:}

Ante Biško, e-mail: abisko@agr.hr, Vesna Jurkić, Sanja Slunjski, Lepomir Čoga

Sveučilište u Zagrebu, Agronomski fakultet, Zavod za ishranu bilja, Svetošimunska 25, 10000 Zagreb

Bernardica Milinović,

Hrvatski centar za poljoprivredu, hranu i selo, Zavod za voćarstvo;

Gorice 68B, 10000 Zagreb,

Zvonimir Savić,

Nova Ves 53, 10000 Zagreb 
